Russian Academy of Sciences, Far Eastern Branch

Botanical Garden-Institute

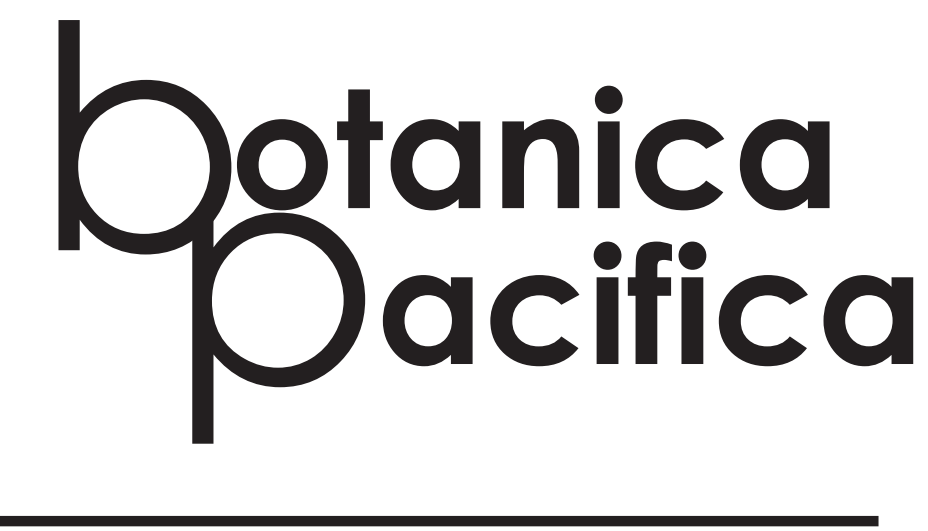

A JOURNAL OF PLANT SCIENCE
AND CONSERVATION

VOLUME 9, NO. 12020 


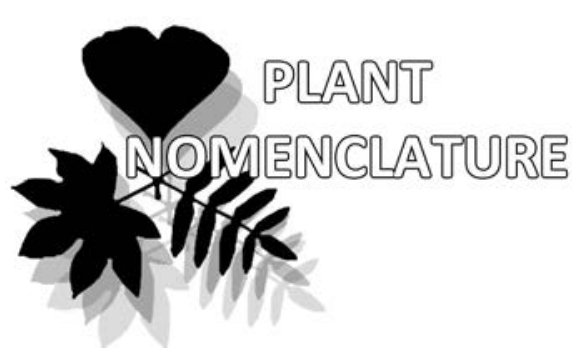

\title{
Typification and the current taxonomic status of Laminaria agarum var. asiaticum and Laminaria boryi (Agaraceae, Laminariales)
}

\author{
Anna V. Klimova*, Tatyana A. Klochkova \& Nina G. Klochkova
}

Anna V. Klimova*

e-mail: annaklimovae@mail.ru

Tatyana A. Klochkova

e-mail: tatyana_algae@mail.ru

Nina G. Klochkova

e-mail: ninakl@mail.ru

Kamchatka State Technical University, Petropavlovsk-Kamchatsky, Russia

* corresponding author

Manuscript received: 18.02 .2020 Review completed: 15.04.2020

Accepted for publication: 20.04.2020

Published online: 23.04 .2020

\begin{abstract}
A B S T R A C T
Lectotypes are designated for Laminaria agarum var. asiaticum and Laminaria boryi and a historical background for the typification of these names is provided. These taxa were described by De la Pylaie in 1830, according to materials collected from Kamchatka (northwest Pacific) and Newfoundland (northwest Atlantic), respectively. Based on the modern data of morphological features and distributional range of Agarum species in the World Ocean, we consider these taxa as synonyms of Agarum clathratum subsp. clathratum, that has wide distribution in the Northern Hemisphere. Ke y w o r d s : lectotypification, taxonomic revision, Kamchatka, Newfoundland, Laminaria agarum var. asiaticum, Laminaria boryi, Laminariales
\end{abstract}

\section{P E 3 Ю M E}

КАимова А.В., КАочкова Т.А., КАочкова Н.Г. Типификация и современный таксономический статус Laminaria agarum var. asiaticum и Laminaria boryi (Agaraceae, Laminariales). В статье обозначены мектотипы названий Laminaria agarum var. asiaticum и Laminaria boryi и Аано историческое обоснование Аля их типификации. Эти таксоны были описаны де Аа Пиляи в 1830 г. по материалам, собранным у берегов Камчатки (северо-западная часть Тихого океана) и Ньюфаундленда (северо-западная часть Атлантического океана). На основе современных данных по морфологии и распространению представителей рода Agarum в Мировом океане, преАложено рассматривать указанные выше таксоны в качестве синонимов широко распространенной в Северном Полушарии маминариевой водоросли Agarum clathratum subsp. clathratum.

КАючевые слова: Аектотипификация, таксономическая ревизия, Камчатка, Ньюфаундленд, Laminaria agarum var. asiaticum, Laminaria boryi, Laminariales
The first member of the genus Agarum Dumort. was described as Fucus agarum S.G. Gmelin in the second half of the 18th century (Gmelin 1768). Before segregation of the genus Agarum by Dumortier into a single taxon in 1822, its members were designated under different generic names, including also the genus Laminaria J.V. Lamour. (Agardh 1817). In 1840, species of Agarum and related taxa (viz. Costaria Grev., Thalassiophyllum Postels \& Rupr.) were included in the family Agaraceae by Postels \& Ruprecht (1840). Species of Agarum are important in sublittoral habitats because they often dominate communities at a depth of 10 to $30 \mathrm{~m}$ (Gagnon et al. 2005).

As discussed in the present study, Laminaria agarum (S.G. Gmelin) C. Agardh var. asiaticum Bach.Pyl. and L. boryi Bach.Pyl. show a typical morphology for members of the genus Agarum. Typification of these two names allows clarification of the taxonomic status of these taxa with subsequent synonymising of them with Agarum clathratum Dumort.

Our study is based on an analysis of algological literature (Gmelin 1768, Stackhouse 1816, Agardh 1817, Dumortier 1822, Bory 1826, De la Pylaie 1830, Postels \& Ruprecht 1840, Silva 1991, Boo et al. 2011, Kawai et al. 2017). The authors of this paper have examined living populations of Agarum species in the field on the different coasts of Russian Far Eastern seas viz. southeast Kamchatka, Bering Island,
Kuril Islands and South Sakhalin. We also have studied herbarium specimens of Agarum that belong to the original material from the Komarov Botanical Institute RAS (LE) and other Agarum specimens using online herbarium databases at PC, BM, ALAJ, NHA, MASS, MAINE, FH and NY (open access https://macroalgae.org/portal/). Herbarium codes are given according to Triers (2020). Abbreviations of authors names are given according to IPNI (2020). The protologues, type specimens of all species, information from AlgaeBase (2020) and Index Nominum Algarum (2020) databases were analyzed during our research.

\section{Historical background}

The "Flora de l'Ile Terre-Neuve et des Filles Saint Pierre et Miquelon" by De la Pylaie (Bachelot de la Pylaie 1830) presents a floristic summary of marine macroalgae from Newfoundland, Saint Pierre and Miquelon based on the study of personal algal materials collected during his expedition on the frigate "Cybele" (1816-1819) in the northwest part of the Atlantic ocean (Gillot 1953), and also on the study of samples from marine algal collections held in Paris National Museum of Natural History (PC). While working with specimens from the museum, De la Pylaie consulted with Bory de St-Vincent. In his work, De la Pylaie described 72 species and 28 varieties of algae and propo- 
sed the division of kelp into orders, sections and genera (Ordre, Sections and Genres; Bachelot de la Pylaie 1830: 23). Among genera included in his table Bachelot de la Pylaie (1830: 28) listed Myriotrema Bach.Pyl. and its type species "Lam. agarum". However, the latter species corresponds to the description of the genus Agarum in its modern understanding. Among laminariaceaen algae, he listed Laminaria boryi and Laminaria agarum (Bachelot de la Pylaie 1830: 28). The first species, $L$. boryi, was described as a novel taxon and in the case of the second species, which was previously described by Agardh (1817), De la Pylaie (1830: 28) described a new variety, Laminaria agarum var. asiaticum, with plants having unbranched stipe and perforated blade with a central midrib, which differed from the typical form of this species. Nowadays, species with that morphology belong to Agarum.

By the time De la Pylaie's work was published, Agarum species had been known under the generic names Orgyia (Stackh.) Duby (1816), Laminaria (1817) and Agarum Bory (1826). Prior to Silva's publication (Silva 1991), Bory de StVincent was considered as the author of the genus Agarum (Postels \& Ruprecht 1840, Klochkova 1998). Silva (1991) clarified that the authorship of the genus belonged to Dumortier (1822), since he published a description of Agarum four years earlier than Bory (1826). Thus, the name, Myriotrema, should be treated as a superfluous name, according to Articles 52.1, and 52.2 of the ICN (Turland et al. 2018).

The new variety, Laminaria agarum var. asiaticum, was described by De la Pylaie based on the specimen from Kamchatka, which was held in Bory de Saint-Vincent's collection (Bachelot de la Pylaie 1830: 28). However, he did not indicate collection site, time or collector in the protologue and did not provide an illustration of the specimen. In his description of Laminaria agarum var. asiaticum, de la Pylaie noted that it differed from the typical variety of $L$. agarum (=A. clathratum $)$ in having oval-shaped basal part of the blade and thus could be identified as a separate species, if only this character was stable "cette plante pourrait être considérée comme espèce, si sa forme était constante” (De la Pylaie 1830: 28).

After studying Bory de Saint-Vincent's specimens, De la Pylaie also described the species Laminaria boryi (De la Pylaie 1830: 28). In his protologue, he indicated the collection site, "Terre-Neuve" [Newfoundland], and the collector, Lamouroux. He also provided size characteristics in the species description (40-50 cm long and $30 \mathrm{~cm}$ wide) and noted the presence of a thin smooth-edged blade. However, he did not illustrate $L$. boryi.

\section{Typification}

Bory de Saint-Vincent's collection is currently stored in the Herbarium of the Muséum National d'Histoire Naturelle, Paris (PC). In this collection, two herbarium sheets of Agarum collected near the coast of Kamchatka are present with the following annotations: "Herbier Bory de St-Vincent" and "Orgyia Boryl" (PC 0579383 and PC 0579386). Thus, it could be suggested that the generic name Orgyia was originally used for Agarum by Bory de Saint-Vincent, but he abandoned this name later and replaced it with Agarum (Bory 1826, De la Pylaie 1830: 24).

The herbarium sheet PC 0579383 (Fig. 1) contains a handwritten annotation in French “... Laminaria agarum $\beta$ asiaticum ... Kamtchatke...", which most likely was made by De la Pylaie. In addition, the following label was later attached to this herbarium sheet "Herb. G. Thuret; Agarum Turneri, Post. et Rupr.; Laminaria Agarum, var. Asiatica La Pylaie, Fl. de Terre-Neuve, p. 28". The first annotation clearly indicated that this specimen was studied by De la Pylaie and was used to describe var. asiaticum.

Another specimen from Kamchatka (PC 0579386) is represented by a fragment of the blade without central midrib, and it has an annotation "Tilesius" in its upper right corner and the following text in the lower part "Fucus Clathrus ... Agarum Gmelin Camtschatca ... Par Tilesius". According to information on its label, this specimen was later identified as Agarum cribrosum Bory by Rostafuiski. To the best of our knowledge, Bory de Saint-Vincent's collection does not contain other specimens from the genus Agarum collected near the coast of Kamchatka and identified as "Laminaria agarum var. asiaticum".

In addition to the herbarium sheets discussed above, Bory de Saint-Vincent's collection in PC includes three specimens (PC 0579387, PC 0579390, PC 0579391) collected from the northwest Atlantic and identified as "Orgyia Boryl". For each specimen, the collector was indicated as Dèspréaux (PC 0579387), Lyngbye (PC 0579390), and Lamouroux (PC 0579391). Several handwritten annotations in French are present on PC 0579391 (Fig. 2), such as "Orgyia Boryl" and "A fronde mince, ... ovale: ... par Lamouroux en 1824; Comme de Terre-Neuve". In addition, it has two labels, each having the mark "Herb. G. Thuref". Also, one of these labels has an annotation "Agarum Turneri, Post. et Rupr.; Laminaria Boryi, La Pylaie (Fl. de Terre-Neuve, p. 28)" and another has the note "Agarum cribrosum, Bory ...". It is noteworthy that the collection site and collector correspond to those indicated in the protologue of L. boryi (Bachelot de la Pylaie 1830). Therefore, we believe that PC 0579391 is an authentic specimen and was used to describe $L$. boryi.

Thus, according to ICN Art. 9.11 (Turland et al. 2018), we selected lectotypes for L. agarum var. asiaticum and L. boryi from Bory de Saint-Vincent's collection.

\section{Current taxonomic status of Laminaria agarum var. asiaticum and L. boryi}

The names, Laminaria agarum var. asiaticum and L. boryi, are validly published according to the ICN (Turland et al. 2018). However, these names were not mentioned in taxonomic revisions of the genus Agarum (Silva 1991, Boo et al. 2011, Kawai et al. 2017). The only reference to L. boryi, excluding the original description by De la Pylaie (1830: 28), is available in the INA database (Silva 2020). L. agarum var. asiaticum is also indicated here as an unconfirmed identification ('cf.') and listed as Agarum asiaticum. The record of A. asiaticum is available in AlgaeBase (Guiry \& Guiry 2020). In all cases only the original source (De la Pylaie 1830: 28) is cited when referring to these taxa. De la Pylaie did not publish the name $A$. asiaticum in his article (1830: 28) and furthermore, to our knowledge, the transfer of $L$. agarum var. asiaticum into the genus Agarum, according to the ICN rules, was not made. The absence of mentions of Laminaria agarum var. asiaticum and L. boryi in the current revisions and 


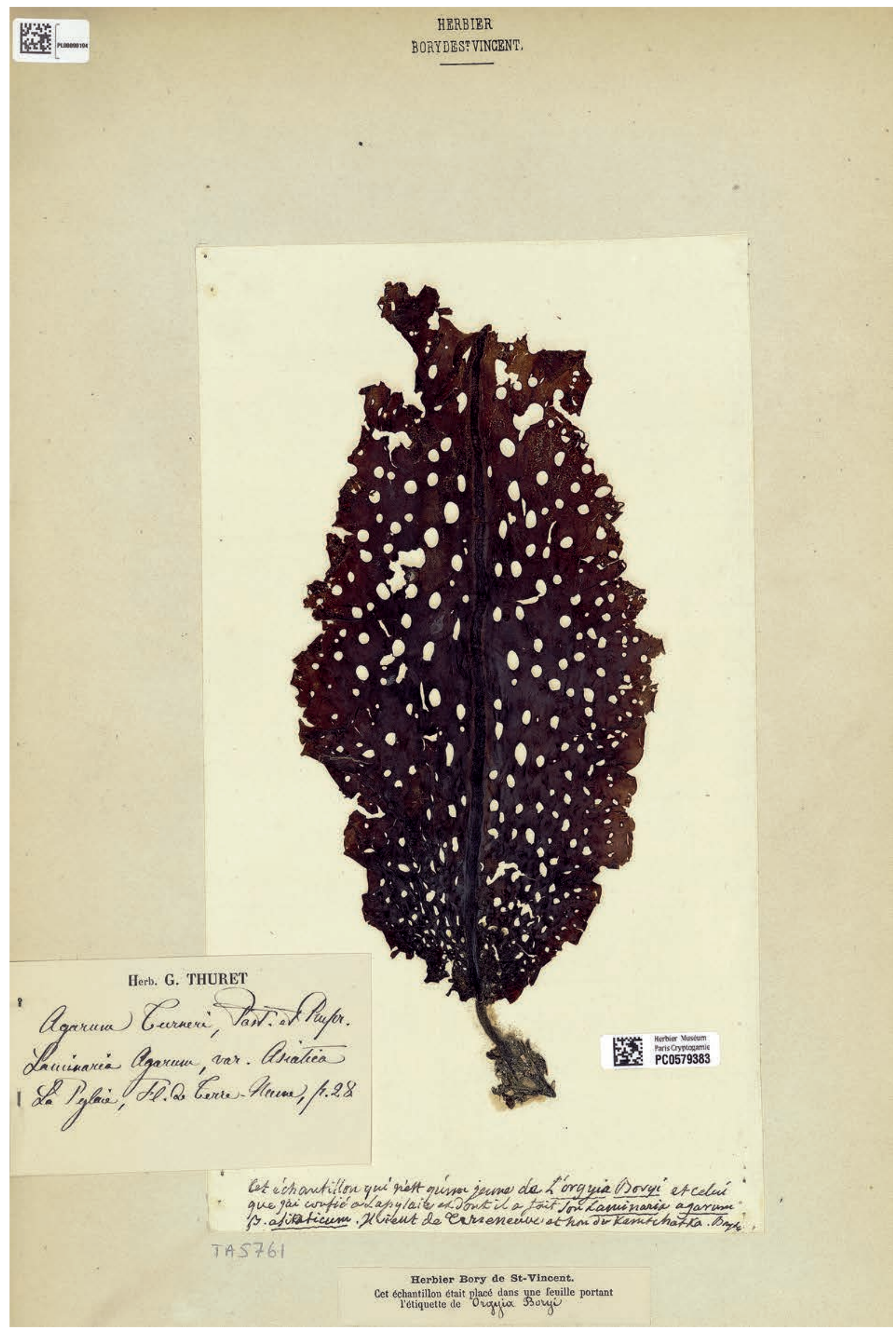

Figure 1 Lectotype of Laminaria agarum var. asiaticum De la Pylaie ([PC0579383, digital image!], PC, Lectotype). Image of the lectotype is available at https://science.mnhn.fr/institution/mnhn/collection/pc/item/pc0579383?listIndex=74\&listCount=115 


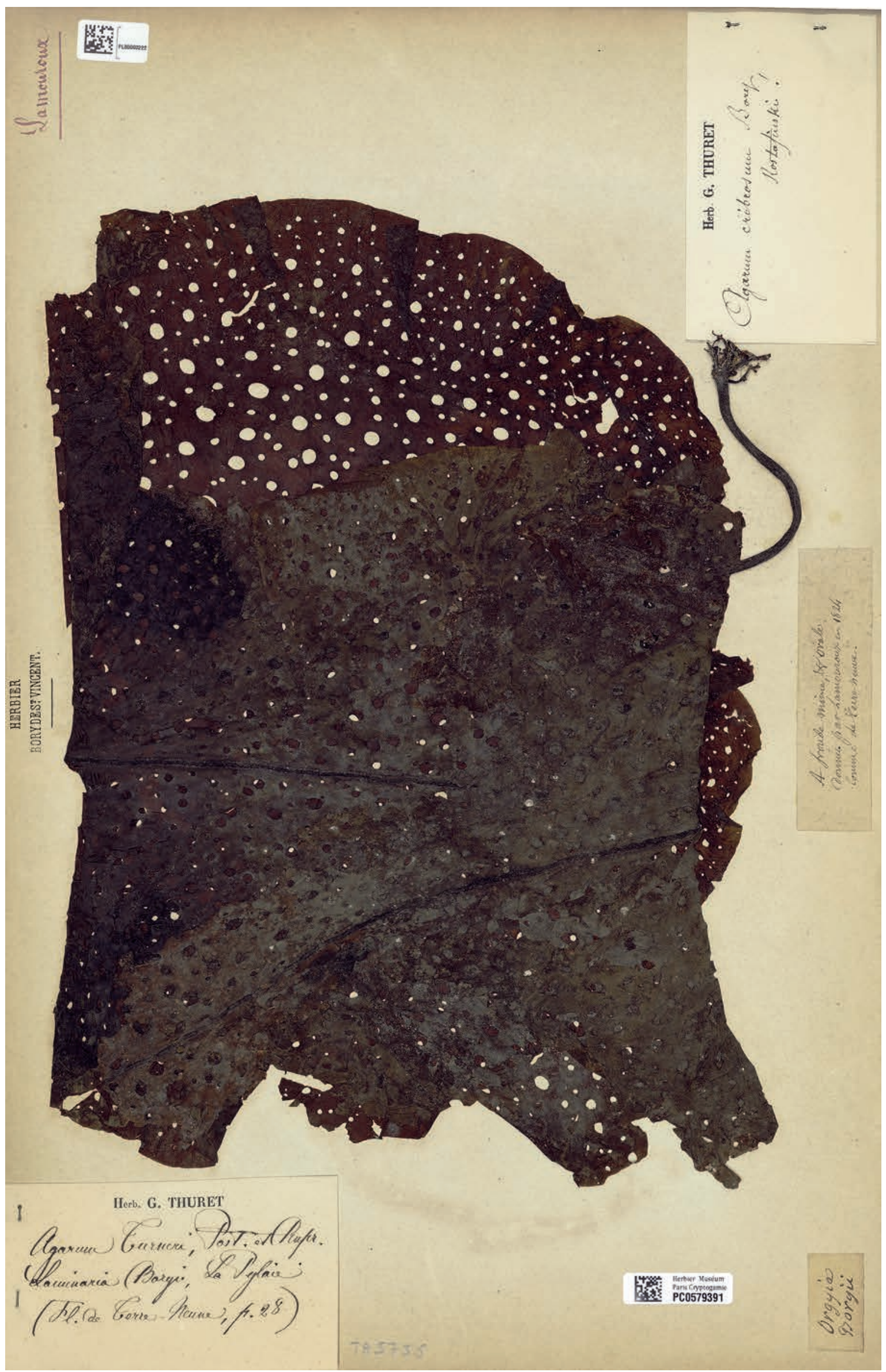

Figure 2 Lectotype of Laminaria boryi De la Pylaie (Lamouroux s.n. [PC0579391, digital image!], PC, Lectotype). Image of the lectotype is available at https://science.mnhn.fr/institution/mnhn/collection/pc/item/pc0579391?listlndex=80\&listCount=115 
floristic studies gives us a reason not to consider them as accepted taxa.

During the last 10 years, several taxonomic revisions were conducted for the genus Agarum (Boo et al. 2011, Kawai et al. 2017). Based on current analysis of their morphological and genetic characteristics, only two species, A. clathratum (1822: 102) and $A$. turneri (1840: 12), are accepted. Among them, only $A$. clathratum is widespread in the Northern Hemisphere and is found in the Pacific, Atlantic and Arctic oceans (Guiry \& Guiry 2020). The remaining species are found only near the Asian coast of the Pacific Ocean. A. turneri is distributed from Kamchatka to Alas$\mathrm{ka}$, including the Aleutian Islands (Klochkova et al. 2009, Lindeberg \& Lindstrom 2010, Boo et al. 2011). Both species, $A$. clathratum and $A$. turneri, were described from Kamchatka (Gmelin 1768, Postels \& Ruprecht 1840).

A. clathratum and $A$. turneri are distinguished in gross morphology of sporophytes (i.e. blade shape, thick/flat midrib, perforations, locations of sporangial sori). The morphological features given in the protologues of L. agarum var. asiaticum and $L$. boryi uniquely correspond to the description of A. clathratum subsp. clathratum (neotype specimen, N. Klochkova 001!, LE), this clearly indicated that both taxa are conspecific with $A$. clathratum. We consider $L$. agarum var. asiaticum and $L$. boryi as heterotypic synonyms of $A$. clathratum.

\section{Agarum clathratum subsp. clathratum}

= Laminaria agarum var. asiaticum (as "Laminaria agarum $\beta$ asiaticum") De la Pylaie (1830: 28).

Lectotype (here designated): - RUSSIA. Kamchatka: Accurate location is not indicated, no date, collector is not identified (PC 0579383! [seen digital image!]). Figure 1.

= Laminaria boryi (as "Laminaria Boryi") De la Pylaie (1830: 28).

Lectotype (here designated): - CANADA. Newfoundland: Accurate location not indicated, 1824, J.V. Lamouroux s.n. (PC 0579391! [seen digital image!]). Figure 2.

\section{ACKNOWLEDGEMENTS}

This study was supported by the Russian Fund for Basic Research (RFBR), research project № 19-04-00285 A to TAK). The authors of this paper are grateful for the comments and suggestions of anonymous reviewers and editors.

\section{LITERATURE CITED}

Agardh, C.A. 1817. Synopsis algarum Scandinaviae, adjecta dispositione universali algarum. Ex officina Berlingiana, Lundae, 135 pp.

Bachelot de la Pylaie, A.J.M. 1830 '1829'. Flora de l'Ile TerreNeuve et des Iles Saint Pierre et Miclon. Livraison [Algae]. No. 24. Typographie de A. Firmin Didot, rue Jacob, Paris, 128 pp.

Boo, G.H., S.C. Lindstrom, N.C. Klochkova, N. Yotsukura, E.C. Yang, H.G. Kim, J.R. Waaland, G.Y. Cho, K.A. Miller \& S.M. Boo 2011. Taxonomy and biogeography of Agarum and Thalassiophyllum (Laminariales, Phaeophyceae) based on sequences of nuclear, mitochondrial, and plastid markers. Taxon 60(3):831-840.

Bory de Saint-Vincent, J.B.G.M. 1826. Laminaire, Laminaria. In: Dictionnaire Classique d'Histoire Naturell, vol. 9, pp. 187-194. Rey \& Gravier, Paris.
Dumortier, B.C. J. 1822. Commentationes Botanicae. Ch. Casterman-Dien, Tournay, $116 \mathrm{pp}$.

Gagnon, P., L.E. Johnson \& J.H. Himmelman 2005. Kelp patch dynamics in the face of intense herbivory: stability of Agarum clathratum (Phaeophyta) stands and associated flora on urchin barrens. Journal of Phycology 41:498-505.

Gillot, G. 1951. Bachelot de la Pylaie (1786-1856). Mémoires de la Société d'histoire et d'archéologie de Bretagne 31:65-136.

Gmelin, S.G. 1768. Historia fucorum. Academia Scientiarum, St. Petersburg, 239 pp.

Guiry, M.D. \& G.M. Guiry 2010. AlgaeBase. World-wide electronic publication, National University of Ireland, Galway. Available from: http://www.algaebase.org. Last accessed 17.02.2020.

Harvey, W.H. 1862. Notice of a collection of algae made on the northwest coast of North America, chiefly at Vancouver Island, by David Lyall, Esq., M.D., R.N., in the years 1859-1861. Journal of the Proceedings of the Linnean Society. Botany 6:157-177.

IPNI: International Plant Names Index 2020. Available from: https://beta.ipni.org. Last accessed 01.03.2020.

Kawai, H., T. Hanyuda, X. Gao, M. Terauchi, M. Miyata, S.C. Lindstrom, N.G. Klochkova \& K.A. Miller 2017. Taxonomic revision of the Agaraceae with a description of Neoagarum gen. nov. and reinstatement of Thalassiophyllum. Journal of Phycology 53(2):261-270.

Klochkova, N.G., T.N. Korolyova \& A.E. Kusidi 2009. Atlas of marine algae of Kamchatka and surrounding areas. KamchatNIRO Press, Petropavlovsk-Kamcharsky, 218 pp.

Lindeberg, M.R. \& S.C. Lindstrom 2010. Field guide to seaweeds of Alaska. Alaska Sea Grant College Program, Fairbanks. Available from: http://www.seaweedsofalaska. com/. Last accessed 17.02.2020.

Postels, A. \& F. Ruprecht 1840. Illustrationes algarum in itinere circum orbem jussu imperatoris Nicolai I. Atque auspiciis navarchi Friderici Lütke annis 1826, 1827, 1828 et 1829 celoce Seniavin exsecuto in Oceano pacifico, inprimis septemtrionale ad littora rossica asiatico-americana collectarum. Typis Eduardi Pratz, Petropoli, 28 pp.

Silva, P.C. 1991. Nomenclatural remarks on Agarum (Laminariaceae, Phaeophyceae). Japanese Journal of Phycology 39:217-221.

Silva, P.C. 2020. Index Nominum Algarum. Herbarium of the University of California Berkeley. Available from: https:/ / ucjeps.berkeley.edu/ina/ Last accessed 17.02.2020.

Stackhouse, J. 1816. Nereis Britannica Editio altera. Nova addita classificatione cryptogamiarum respectu generis Fuci.: Excudebat S. Collingwood, Oxonii [Oxford], 68 pp.

Thiers, B. (ed.) 2020. [Continuously updated] Index Herbariorum: A global directory of public herbaria and associated staff. New York Botanical Garden's Virtual Herbarium. Available from: http:/ / sweetgum.nybg.org/science/ih/ Last accessed 01.03.2020.

Turland, N.J., J.H. Wiersema, F.R. Barrie, W. Greuter, D.L. Hawksworth, P.S. Herendeen, S. Knapp, W.-H Kusber, D.-Z. Li, K. Marhold, T.W. May, J. McNeill, A.M. Monro, J. Prado, M.J. Price \& G.F. Smith (eds) 2018. International Code of Nomenclature for algae, fungi, and plants (Shenzhen Code) adopted by the Nineteenth International Botanical Congress Shenzhen, China, July 2017. Regnum Vegetabile 159. Koeltz Botanical Books, Glashütten, 254 pp. 